\title{
UPAYA MENINGKATKAN KEMAMPUAN GURU PENDIDIKAN AGAMA ISLAM DALAM PENGGUNAAN MEDIA PEMBELAJARAN MELALUI SUPERVISI AKADEMIK DI SMP NEGERI 3 MARABAHAN
}

\author{
M. Riduan \\ Kemenag, Kabupaten Barito Kuala \\ Email: mriiduan@gmail.com
}

\begin{abstract}
Teacher is one important factor in the provision of education in schools. As professionals, teachers must be able to plan learning, improve the quality of the learning process and being able to use instructional media. The problems of this study are: Is the ongoing academic supervision can improve the ability of teachers to use instructional media. Does the teacher is able to optimize the use of instructional media. Bagaaimanakah perception of teachers and students in learning to use the media LCD projector. The research location is SMP Negeri 3 Marabahan Barito Kuala with data collection techniques such as observation, interviews, and questionnaires students. The results showed that both the RPP assessment, activities of students and teachers in the classroom, observation of activities of students and teachers have been categorized quite well with the average value $(71.74 \%)$ in cycle 1 and categories with average values $(80,54 \%)$ in cycle 2 . thus the indicators of achievement has been exceeded or in other words, the study was discontinued because it meets the target.
\end{abstract}

Keywords: media learning, action research schools, LCD projector

\begin{abstract}
ABSTRAK
Guru adalah salah satu faktor penting dalam penyelenggaraan pendidikan di sekolah. Sebagai tenaga professional, guru harus mampu membuat perencanaan pembelajaran, meningkatkan kualitas proses pembelajaran dan mampu menggunakan media pembelajaran. Rumusan masalah dalam penelitian ini yaitu : Apakah supervisi akademik berkelanjutan mampu meningkatkan kemampuan guru dalam penggunaan media pembelajaran. Apakah guru mampu mengoptimalkan penggunaan media pembelajaran. Bagaaimanakah persepsi guru dan siswa dalam pembelajaran menggunakan media LCD proyektor. Lokasi penelitian adalah SMP Negeri 3 Marabahan Kabupaten Barito Kuala dengan teknik pengumpulan data berupa observasi, wawancara, dan angket siswa. Hasil penelitian menunjukkan bahwa baik penilaian RPP, aktivitas siswa maupun guru di kelas, pengamatan aktivitas siswa dan guru sudah masuk kategori cukup baik dengan nilai ratarata $(71,74 \%)$ pada siklus 1 serta kategori baik dengan nilai rata-rata $(80,54 \%)$ pada siklus 2. Dengan demikian indikator pencapaian sudah terlampaui atau dengan kata lain penelitian dihentikan karena sudah memenuhi sasaran.
\end{abstract}

Kata Kunci : media pembelajaran, penelitian tindakan sekolah, LCD proyektor 


\section{PENDAHULUAN}

Perubahan diberbagai sektor kehidupan kian bertambah. Permasalahan muncul silih berganti. Perkembangan teknologi informasi dengan leluasa memperkenalkan manusia pada gaya hidup (life style) dan ujung-ujungnya sistem sosial mengalami perubahan drastis. Dalam menghadapi itu semua, manusia dituntut untuk responsif, inovatif, dan kreatif dalam menyesuaikan tantangan zamannya. Ketidakmampuan merespon tantangan zaman hanya akan menjadikan manusia terseret oleh arus perubahan yang terjadi di masyarakat.

Dinamika kehidupan sangat cepat berubah atau mengalami perkembangan kearah yang lebih baik, simpel dan praktis. Artinya jika kita dapat mengikuti perkembangan zaman yang serba modern seperti sekarang ini tentu akan memudahkan dalam menyelesaikan semua pekerjaan. Oleh karena itu, guru pendidikan Agama Islam harus mampu mengikuti perkembangan zaman supaya tidak ketinggalan kereta. Dalam bahasa Arab, kata guru dikenal dengan istilah muallim, murrabbi, mudarris, muaddib, dan ustadz. Menurut Bunyamin (2007), beberapa istilah itu memiliki makna yang berbeda, sesuai dengan konteks kalimatnya, walaupun memamng dalam konteks tertentu mempunyai kesamaan makna. Adapun pengertian guru secara terminologi, sebagaimana ditulis Hadari Nawawi (1989), adalah orang yang kerjanya mengajar atau memberikan pelajaran di sekolah atau kelas. Secara lebih khusus, guru berarti orang yang bekerja dalam bidang pendidikan dan pengajaran yang ikut bertanggungjawab dalam membantu anak-anak mencapai kedewasaan masing-masing.

Guru adalah salah satu faktor penting dalam penyelenggaran pendidikan di sekolah. Oleh karena itu, meningkatkan mutu pendidikan berarti meningkatkan mutu guru. Meningkatkan mutu guru bukan hanya dari segi kesejahteraannya, tetapi juga profesionalitasnya. Sejalan 42 dengan hal itu UU RI No. 14 tahun 2005 Bab ll Pasal 2 ayat (1) menyatakan guru mempunyai kedudukan sebagai tenaga professional pada jenjang pendidikan dasar, pendidikan menengah, dan pendidikan anak usia dini pada jalur pendidikan formal yang diangkat sesuai dengan peraturan perundang-undangan. Profesional berarti melakukan sesuatu sebagai pekerjaan pokok sebagai profesi dan bukan sebagai pengisi waktu luang atau sebagai hobi belaka.

Guru yang terjamin kualitasnya diyakini mampu melaksanakan tugas dan fungsinya dengan baik. Penjaminan mutu guru perlu dilakukan dari waktu ke waktu demi terselenggaranya layanan pembelajaran yang berkualitas. Guru yang bermutu niscaya mampu melaksanakan pendidikan, pengajaran dan pelatihan yang baik dan efisien. Guru memiliki peran yang sangat penting dalam menentukan kuantitas dan kualitas pengajaran yang dilaksanakannya. Oleh sebab itu, guru harus memikirkan dan membuat perencanaan pembelajaran secara saksama dalam meningkatkan kesempatan belajar bagi siswanya dan memperbaiki kualitas mengajarnya. Guru wajib memiliki kualifikasi akademik, kompetensi, sertifikat pendidik, sehat jasmani dan rohani, serta memiliki kemampuan untuk mewujudkan tujuan pendidikan nasional (Djamarah\&Aswan, 2006). Kompetensi guru meliputi kompetensi pedagogik, kompetensi kepribadian, kompetensi sosial dan kompetensi professional yang diperoleh melalui pendidikan profesi.

Pendidikan Agama Islam diharapkan menghasilkan manusia yang selalu berupaya menyempurnakan iman, takwa, dan akhlak serta membangun peradaban dan keharmonisan kehidupan, khususnya dalam memajukan peradaban bangsa yang bermartabat. Manusia seperti itu diharapkan tangguh dalam menghadapi tantangan, hambatan dan perubahan yang muncul dalam pergaulan masyarakat baik 
dalam lingkup lokal, nasional, regional maupun global.

Pembelajaran akan lebih baik jika didukung oleh alat yang memudahkan siswa dalam belajar misalnya media pembelajaran. Menurut terminologi, kata media berasal dari bahasa latin "medium" yang artinya perantara atau pengantar. Media adalah perantara atau pengantar pesan dari pengirim ke penerima pesanan (Sadiman dkk., 1990; Arsyad, 2014). Media pembelajaran adalah media yang digunakan dalam pembelajaran, yaitu meliputi alat bantu guru dalam mengajar serta sarana pembawa pesan dari sumber belajar ke penerima pesan belajar (siswa). Jika guru memanfaatkan berbagai media pembelajaran secara baik, guru dapat berbagi peran dengan media (Rudi\& Cepy, 2007). Peran guru akan lebih mengarah sebagai manajer pembelajaran dan bertanggung jawab menciptakan kondisi sedemikian rupa agar siswa dapat belajar. Untuk itu guru lebih berfungsi sebagai penasehat, pembimbing, motivator dan fasilitator dalam kegiatan belajar mengajar.

Penggunaan laptop dan LCD Proyektor pada proses belajar mengajar akan memberikan hasil yang optimal dan merupakan jenis media pembelajaran yang cukup komplit dalam penyajiannya karena dapat menyajikan atau memvisualisasikan pembelajaran berupa gambar, suara, halaman cetak, slide, video, film dan lainlain.

Laptop dan LCD Proyektor dapat dipakai sebagai media pembelajaran untuk semua bidang studi sesuai dengan karakteristik materi masing-masing. Untuk membuat desain Powerpoint yang baik dibutuhkan kemampuan khusus, sehingga para guru perlu mempelajari cara mendesain pesan dengan baik agar tampilannya dapat menumbuhkan minat belajar siswa sehingga siswa dapat belajar dengan mudah.

Perpaduan antara Laptop dengan LCD Proyektor dapat menyajikan pesan atau materi pembelajaran sesuai desain/rancangan yang telah disiapkan. Desain pesan dapat berwujud : Audio, Visual Diam, Visual Gerak, atau Audio Visual Gerak. Dengan tampilan penuh warna (Full Colour) sangat menarik minat dan perhatian siswa dalam mengikuti proses pembelajaran (Slameto, 2003).

\section{METODE PENELITIAN}

Penelitian berlokasi di SMP Negeri 3 Marabahan Jalan Jenderal Sudirman No. 75, Kelurahan Ulu Benteng, Kecamatan Marabahan Kabupaten Barito Kuala Propinsi Kalimantan Selatan yang dilakukan selama bulan Maret-Mei 2015. Sasaran penelitian ini adalah (2) dua orang guru mata pelajaran Pendidikan Agama Islam di SMP Negeri 3 Marabahan, yaitu Mursyidah, S.Ag. dan Aspihannoor, S.Pd.I.

Teknik pengumpulan data menggunakan instrumen penelitian yakni observasi, wawancara, dan angket siswa. Data hasil observasi tentang aktivitas siswa dan aktivitas guru dalam mengelola pembelajaran menggunakan media pembelajaran LCD Proyektor dianalisis dengan menghitung nilai rata-rata seluruh aspek dari beberapa kali pertemuan yang dilaksanakan. Selanjutnya nilai rata-rata tersebut direfleksikan dengan kriteria pada Tabel 1 dengan indikator keberhasilan pada Tabel 2.

Tabel 1. Interpretasi Data Hasil Observasi

\begin{tabular}{lc}
\hline \multicolumn{1}{c}{ Nilai } & Kriteria \\
\hline $0-<55 \%$ & Kurang Baik \\
\hline $55 \%-<75 \%$ & Cukup Baik \\
\hline $75 \%-<90 \%$ & Baik \\
\hline $90 \%-100 \%$ & Sangat Baik \\
\hline
\end{tabular}

Tabel 2. Indikator Keberhasilan

\begin{tabular}{llcc}
\hline No & \multicolumn{2}{c}{ Indikator } & $\begin{array}{c}\text { Skor (rata-rata) } \\
\text { minimal }\end{array}$ \\
\hline 1 & $\begin{array}{l}\text { Pendidik dapat membuat } \\
\text { program pengajaran }\end{array}$ & $75 \%$ \\
& $\begin{array}{l}\text { dengan baik dan benar } \\
\text { sesuai ketentuan yang } \\
\text { berlaku }\end{array}$ & \\
\hline 2 & $\begin{array}{l}\text { Pendidik } \\
\text { melakukan }\end{array}$ & dapat & $75 \%$ \\
& & proses & \\
\hline
\end{tabular}




\begin{tabular}{lr}
\hline pembelajaran & dengan \\
menggunakan & media \\
LCD Proyektor dengan & denar sesuai ketentuan \\
benar berlaku & \\
yang be
\end{tabular}

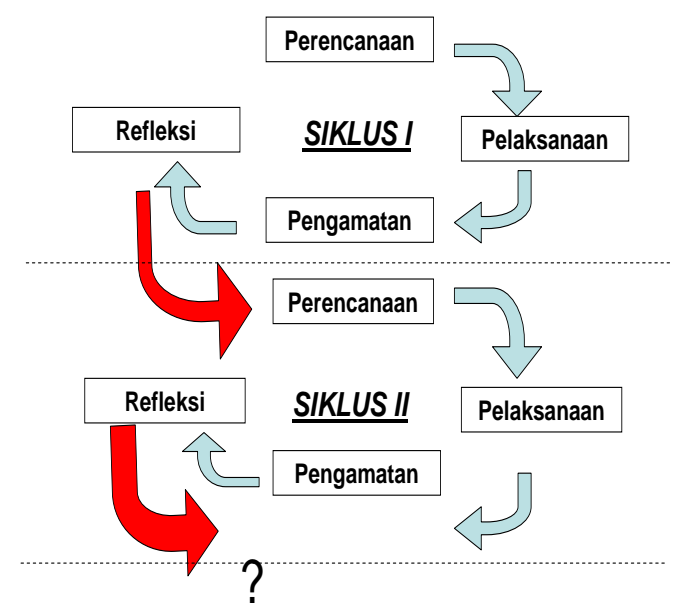

Gambar 1. Langkah-langkah PTS (Direktorat Tendik, 2008)

Penelitian ini menggunakan rancangan penelitian tindakan. Tindakan dalam penelitian ini dirancang dalam 2 siklus (Gambar 1). Masing-masing siklus terdiri atas 4 tahapan, yaitu : (1) perencanaan; (2) pelaksanaan tindakan; (3) pengamatan; dan (5) refleksi. Siklus 2 mengacu pada hasil refleksi pada siklus 1 , maka kegiatan dalam siklus 2 ditekankan pada memperbaiki hal-hal yang kurang dalam pelaksanaan di siklus 1 .

\section{HASIL DAN PEMBAHASAN}

\section{A. Hasil Penelitian}

Siklus 1

Sesuai dengan perencanaan yang telah disusun diawali dengan sosialisasi kepada guru Pendidikan Agama Islam SMP Negeri 3 Marabahan tentang penelitian tindakan yang dilaksanakan oleh Pengawas Pendidikan Agama Islam dalam rangka supervisi akademik yang akan dilaksanakan dalam 2 siklus kegiatan. Tindakan supervisi akademik siklus 1 dilaksanakan dari tanggal 13 sampai dengan 23 Maret 2015, yang dilaksanakan oleh Pengawas. Tindakan yang dilakukan meliputi perencanaan, pelaksanaan, observasi, dan refleksi.

Dalam analisis hasil penilaian supervisi dikelompokkan dalam 3 aspek penilaian yaitu Rencana Pelaksanaan Pembelajaran (RPP), proses pembelajaran, penggunaan LCD Proyektor, dan penilaian peserta didik terhadap proses pembelajaran melalui angket.

\section{Perencanaan}

Dalam perencanaan dilakukan berbagai macam kegiatan yang merupakan langkah awal sebelum pelaksanaan siklus 1 .

Tahapan-tahapannya adalah sebagai berikut :

a. menyusun jadwal sosialisasi dan supervisi yang dilaksanakan oleh supervisor (jadwal terlampir),

b. pembuatan dan memperbanyak lembaran untuk observasi serta menyiapkan instrumen-intrumen untuk penilaian rencana pelaksanaan pembelajaran (terlampir),

c. membuat lembar observasi kegiatan guru mengajar,

d. membuat lembar observasi kegiatan siswa,

e. membuat angket siswa, yaitu penilaian terhadap proses pembelajaran yang dilakukan oleh pendidik atau guru (terlampir).

2. Pelaksanaan

Dalam tahapan ini seluruh rencana yang telah dibuat dilaksanakan dengan kurun waktu pelaksanaan dari mulai sosialisasi dan dilaksanakan dari tanggal 4 Maret sampai dengan 30 April 2015, yaitu melakukan observasi dan supervisi akademik oleh supervisor yang telah di tugaskan dalam jadwal.

3. Observasi

Observasi dan supervisi pada siklus 1 terbagi 3 bagian, yaitu observasi dan penilaian pembuatan perencanaan pembelajaran, penilaian terhadap aktivitas guru, dan penilaian terhadap aktivitas siswa.

a. Penilaian pembuatan perencanaan kegiatan pembelajaran 
Tabel 3. Hasil penilaian Rencana Pelaksanaan Pembelajaran

\begin{tabular}{lll}
\hline ma Guru & Nilai $(\%)$ & \\
\hline $\mathrm{h}$ & 7,27 & $\mathrm{k}$ \\
\hline oo & 5,00 & $\mathrm{k}$ \\
\hline Jumlah & 2,27 & \\
\hline ata-rata & 5,13 & \\
\hline
\end{tabular}

Dari Tabel 3 diketahui bahwa hasil penilaian Rencana Pelaksanaan Pembelajaran (RPP) Pendidikan Agama Islam termasuk dalam kategori baik dengan nilai rata-rata $76,13 \%$.

b. Aktivitas siswa dan guru

Selama kegiatan pembelajaran di kelas berlangsung diadakan pengamatan dan penilaian terhadap aktivitas siswa dan guru. Pengamatan dan penilaian terhadap aktivitas siswa dan guru dilakukan oleh seorang pengamat dengan mengisi lembar observasi aktivitas siswa dan lembar observasi pengelolaan pembelajaran dengan menggunakan media LCD Proyektor.

Berdasarkan hasil pengamatan dan penilaian terhadap aktivitas siswa diperoleh data bahwa semua siswa antusias mengikuti pelajaran terutama pada saat guru menjelaskan materi dengan media LCD Proyektor, namun pada aspek aktif dalam mengerjakan tugas, hanya siswa yang tergolong pandai saja yang aktif mengerjakan tugas. Untuk pengelolaan pembelajaran yang dilakukan oleh guru secara keseluruhan telah berlangsung cukup baik, hanya saja pada aspek penggunaan media LCD Proyektor masih kurang akraktif dan kreatif, pengelolaan waktu pengamat menilai bahwa guru juga masih belum sepenuhnya berhasil melaksanakannya. Selain itu, menurut pengamat pada aspek pemberian motivasi belajar kepada siswa juga dirasakan masih kurang.

Setelah dilakukan perhitungan oleh peneliti, aktivitas siswa di kelas selama pembelajaran Pendidikan Agama Islam berlangsung dapat dilihat pada Tabel 4 berikut :
Tabel 4. Aktivitas Siswa di Kelas Selama Pembelajaran Berlangsung

\begin{tabular}{lll}
\hline \multicolumn{2}{l}{ ıma Guru } & \multicolumn{2}{l}{ Nilai (\%) } \\
\hline [ursyidah & 42 & sup \\
\hline pihannoor &, 86 & sup \\
\hline Jumlah &, 28 & \\
\hline lata-rata &, 64 & \\
\hline
\end{tabular}

Dari Tabel 4 diketahui aktivitas siswa selama pembelajaran Pendidikan Agama Islam berlangsung termasuk dalam kategori cukup baik dengan nilai rata-rata $69,64 \%$. Adapun aktivitas guru di kelas selama pembelajaran berlangsung guru dapat dilihat pada Tabel 5 berikut :

Tabel 5. Aktivitas Guru di Kelas Selama Pembelajaran Berlangsung

\begin{tabular}{lll}
\hline ma Guru & \multicolumn{2}{l}{ Nilai (\%) } \\
\hline ursyidah &, 33 & sup \\
\hline ihannoor &, 33 & sup \\
\hline umlah &, 66 & \\
\hline ata-rata &, 83 & \\
\hline
\end{tabular}

Dari Tabel 5 diketahui aktivitas guru selama pembelajaran Pendidikan Agama Islam berlangsung termasuk dalam kategori cukup baik dengan nilai rata-rata $70,83 \%$.

Tabel 6. Hasil Pengamatan Aktivitas Siswa dalam Pembelajaran Mengguunakan LCD

\begin{tabular}{lll}
\hline ama Guru & \multicolumn{2}{l}{ Nilai (\%) } \\
\hline Iursyidah &, 42 & sup \\
\hline pihannoor &, 85 & sup \\
\hline Jumlah & 1,27 & \\
\hline 2ata-rata &, 63 & \\
\hline
\end{tabular}

Dari Tabel 6 diketahui bahwa hasil pengamatan aktivitas siswa dalam pembelajaran Pendidikan Agama Islam menggunakan LCD Proyektor termasuk dalam kategori cukup baik dengan nilai rata-rata $69,63 \%$.

Tabel 7. Hasil Pengamatan Aktivitas Guru dalam Pembelajaran Menggunakan LCD

\begin{tabular}{lll}
\hline Ima Guru & \multicolumn{2}{l}{ Nilai (\%) } \\
\hline ursyidah & 33 & sup \\
\hline pihannoor & 66 & sup \\
\hline Jumlah &, 99 & \\
\hline aata-rata & 49 & \\
\hline
\end{tabular}


Dari Tabel 7 di atas diketahui bahwa hasil pengamatan aktivitas guru dalam pembelajaran Pendidikan Agama Islam menggunakan LCD Proyektor termasuk dalam kategori cukup baik dengan nilai rata-rata $72,49 \%$.

\section{Refleksi}

Berdasarkan hasil observasi dari pelaksanaan siklus 1, diketahui bahwa Guru sudah mampu membuat dan menyusun semua rencana pelaksanaan pembelajaran $(76,13 \%)$, namun masih ada beberapa kekurangan. Saat proses pembelajaran berlangsung aktivitas siswa cukup baik ( $69,64 \%)$ dan aktivitas guru cukup baik $(72,49 \%)$ dalam pembelajaran Pendidikan Agama Islam meskipun masih kurang bervariasi dalam penyajiannya karena ini baru pertama kali. Pengamatan terhadap aktivitas siswa dalam pembelajaran menggunakan LCD proyektor yang dilakukan oleh pengamat diperoleh data bahwa semua siswa antusias mengikuti pelajaran cukup baik $(69,63 \%)$, namun pada aspek aktif dalam mengerjakan tugas, hanya siswa yang tergolong pandai saja yang aktif mengerjakan tugas. Untuk aktivitas guru yang dilakukan oleh guru secara keseluruhan telah berlangsung cukup baik $(72,49)$, pengelolaan waktu pengamat menilai bahwa guru juga masih belum sepenuhnya berhasil melaksanakannya. Selain itu, menurut pengamat pada aspek pemberian motivasi belajar kepada siswa juga dirasakan masih kurang.

\section{Siklus 2}

Siklus 2 dilaksanakan bulan Mei 2015. Pada dasarnya proses pembelajaran siklus 2 sama seperti siklus 1 . Materi yang disajikan adalah melanjutkan materi pada siklus 1, melakukan pengamatan, wawancara terhadap guru yang mengajar serta memberikan angket kepada siswa untuk mengetahui persepsi siswa terhadap pembelajaran Pendidikan Agama Islam menggunakan media LCD Proyektor.

Siklus 2 juga terdiri dari 4 tahapan tindakan sebagai berikut :

\section{Rencana Tindakan}

Berdasarkan hasil pengamatan dan refleksi pada siklus 1 , maka pada siklus 2 direncanakan kembali tindakan perbaikan terhadap hal-hal yang dianggap masih kurang pada siklus 1, antara lain :

a. Guru harus lebih meningkatkan kemampuannya dalam Penggunaan LCD Proyektor.

b. Pemberian motivasi belajar oleh guru kepada siswa perlu ditingkatkan agar siswa lebih bersemangat dalam mengikuti kegiatan pembelajaran.

c. Penggunaan waktu pada siklus 1 belum efektif sehingga pada siklus 2 waktu pembelajaran harus diatur sebaik mungkin,

d. Pengawasan terhadap kelompok siswa perlu ditingkatkan sehingga tidak ada lagi siswa yang tidak aktif dalam pembelajaran.

2. Pelaksanaan

Dalam tahapan ini seluruh rencana yang telah dibuat dilaksanakan dengan kurun waktu pelaksanaan dari mulai sosialisasi dan dilaksanakan dari tanggal 4 sampai dengan 20 Mei 2015, yaitu melakukan observasi dan supervisi akademik oleh supervisor yang telah di tugaskan dalam jadwal.

3. Observasi

Observasi dan supervisi pada siklus 1 terbagi 3 bagian, yaitu observasi dan penilaian pembuatan perencanaan pembelajaran, penilaian terhadap aktivitas guru, dan penilaian terhadap aktivitas siswa.

a. Penilaian pembuatan perencanaan kegiatan pembelajaran.

Tabel 8. Hasil Penilaian Rencana Pelaksanaan Pembelajaran (RPP)

\begin{tabular}{lll}
\hline Jama Guru & Nilai $(\%)$ & \\
\hline h & 4,09 & $\mathrm{ik}$ \\
\hline oor & 1,81 & $\mathrm{ik}$ \\
\hline Jumlah & 15,90 & \\
\hline Rata-rata & 2,95 & \\
\hline
\end{tabular}

Dari tabel 8 diketahui bahwa hasil penilaian Rencana Pelaksanaan Pembelajaran (RPP) Pendidikan Agama 
Islam termasuk dalam kategori baik dengan nilai rata-rata $82,95 \%$.

b. Penilaian terhadap aktivitas siswa dan guru

Selama kegiatan pembelajaran di kelas berlangsung, diadakan pengamatan dan penilaian terhadap aktivitas siswa dan guru. Pengamatan dan penilaian terhadap aktivitas siswa dan guru dilakukan oleh seorang pengamat dengan mengisi lembar observasi aktivitas siswa dan lembar observasi pengelolaan pembelajaran dengan menggunakan media LCD Proyektor. Berdasarkan hasil pengamatan dan penilaian terhadap aktivitas siswa diperoleh data bahwa semua siswa antusias mengikuti pelajaran terutamaTabel 11. Hasil Pengamatan Aktivitas Siswa dalam pada saat guru menjelaskan materi dengan media LCD Proyektor, namun pada aspek aktif dalam mengerjakan tugas, hanya siswa yang tergolong pandai saja yang aktif mengerjakan tugas. Untuk pengelolaan pembelajaran yang dilakukan oleh guru secara keseluruhan telah berlangsung baik. Dan pada aspek penggunaan media LCD Proyektor baik, akraktif dan kreatif, pengelolaan waktu pengamat menilai bahwa guru juga sepenuhnya berhasil melaksanakannya. Selain itu, menurut pengamat pada aspek pemberian motivasi belajar kepada siswaT juga baik.

Setelah dilakukan perhitungan oleh peneliti, aktivitas siswa di kelas selama pembelajaran Pendidikan Agama Islam berlangsung dapat dilihat pada tabel berikut :

Tabel 9. Aktivitas Siswa di Kelas Selama Pembelajaran Berlangsung

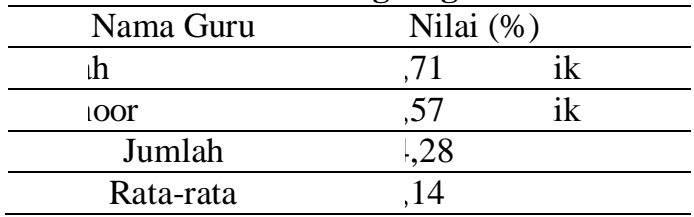

Dari Tabel 9 diketahui aktivitas siswa selama pembelajaran Pendidikan Agama Islam berlangsung termasuk dalam kategori baik dengan nilai rata-rata $82,14 \%$. Adapun aktivitas guru selama pembelajaran berlangsung dapat dilihat pada tabel berikut:

abel 10. Aktivitas Guru di Kelas Selama Pembelajaran Berlangsung

\begin{tabular}{lll}
\hline ıma Guru & \multicolumn{1}{c}{ Nilai(\%) } & \\
\hline ursyidah & 83,33 & ik \\
\hline pihannoor & 81,66 & iik \\
\hline Jumlah & 64,99 & \\
\hline 'ata-rata & 82,49 & \\
\hline
\end{tabular}

Dari Tabel 10 diketahui aktivitas guru selama pembelajaran Pendidikan Agama Islam berlangsung termasuk dalam kategori baik dengan nilai rata-rata $82,49 \%$.

Pembelajaran Menggunakan LCD

\begin{tabular}{ccc}
\hline Nama Guru & \multicolumn{2}{c}{ Nilai (\%) } \\
\hline Mursyidah & 3,57 & Baik \\
\hline Aspihannoor & 5,00 & Baik \\
\hline Jumlah & 3,57 & \\
\hline Rata-rata & 5,79 & \\
\hline
\end{tabular}

Dari Tabel 11 diketahui bahwa hasil pengamatan aktivitas siswa dalam pembelajaran Pendidikan Agama Islam menggunakan LCD Proyektor termasuk dalam kategori baik dengan nilai rata-rata $76,79 \%$.

\begin{tabular}{|c|c|c|}
\hline \multicolumn{3}{|c|}{$\begin{array}{l}\text { Hasil Pengamatan Aktivitas Guru dalam } \\
\text { Pembelajaran Menggunakan LCD }\end{array}$} \\
\hline ama Guru & Nil & \\
\hline Tursyidah & ,00 & ik \\
\hline spihannoor & ,66 & $\mathrm{ik}$ \\
\hline Jumlah & 5,66 & \\
\hline Rata-rata & ,33 & \\
\hline
\end{tabular}

Dari Tabel 12 diketahui bahwa hasil pengamatan aktivitas guru dalam pembelajaran Pendidikan Agama Islam menggunakan LCD Proyektor termasuk dalam kategori baik dengan nilai rata-rata $78,33 \%$.

4. Refleksi

Berdasarkan hasil observasi dan evaluasi siklus 2, diketahui bahwa guru sudah mampu membuat dan menyusun semua rencana pelaksanaan pembelajaran dengan baik dan benar (82,95\%). Penilaian pada saat proses pembelajaran 
aktivitas siswa masuk dalam kategori baik $(82,14 \%)$, dan aktivitas guru selama pembelajaran Pendidikan Agama Islam berlangsung kategore baik rata-rata $(82,49 \%)$. Pengamatan terhadap aktivitas siswa yang dilakukan oleh pengamat dalam pembelajaran menggunakan LCD proyektor diperoleh data masuk kategori baik dengan rata-rata $(76,79 \%)$, bahwa semua siswa antusias mengikuti pelajaran, semua aspek aktivitas siswa dalam pembelajaran sudah terpenuhi. Hasil pengamatan dan penilaian terhadap aktivitas guru dalam mengelola pembelajaran Pendidikan Agama Islam menggunakan LCD proyektor masuk dalam kategori baik $(78,33 \%)$. Guru sudah mampu melaksanakan semua rencana tindakan yang telah dibuat. Pada siklus 2 ini kemampuan guru dalam menggunakan media LCD Proyektor sudah meningkat, dan berdasarkan indikator keberhasilan (75\%) sudah terlampaui. Dan dengan demikian penelitian ini di hentikan, karena sudah tercapai.

\section{Hasil Wawancara terhadap Guru yang Mengajar}

Berdasarkan hasil wawancara dengan guru yang mengajar diperoleh data sebagai berikut :

1. Minat dan perhatian siswa terhadap pelajaran Pendidikan Agama Islam masih kurang.

2. Guru merasa kesulitan dalam memotivasi siswa dan memilih media yang digunakan.

3. Guru belum pernah menggunakan media LCD Proyektor.

4. Guru merasa kesulitan dalam menghubungkan Laptop dan LCD Proyektor.

5. Guru merasa kesulitan dalam membuat bahan ajar dengan Powerpoint.

6. Setelah menerapkan pembelajaran menggunakan LCD Proyektor minat dan perhatian siswa meningkat.

\section{Persepsi Siswa Terhadap Pembelajaran Pendidikan Agama Islam Menggunakan Media LCD Proyektor}

Berdasarkan angket siswa tentang pernah tidaknya guru mengajar dengan pembelajaran menggunakan media LCD Proyektor yang menunjukkan bahwa semua responden menyatakan kadangkadang $(88,23 \%)$, ini termasuk dalam kategori tinggi. Hal ini menunjukkan bahwa media pembelajaran ini kadangkadang saja diterapkan di kelas. Respon siswa tentang senang tidaknya siswa saat pembelajaran menggunakan media LCD Proyektor menunjukkan bahwa responden menyatakan sangat senang $(91,17 \%)$ termasuk dalam kategori tinggi sekali. Hal ini menunjukkan bahwa pada umumnya responden sangat senang saat pembelajaran menggunakan media LCD Proyektor.

Respon siswa tentang mudah tidaknya siswa memahami pelajaran dengan menggunakan media LCD Proyektor yang menunjukkan bahwa responden menyatakan mudah $(94,11 \%)$ termasuk dalam kategori tinggi sekali. Hal ini menunjukkan bahwa pada umumnya responden mudah memahami pelajaran dengan menggunakan media LCD Proyektor.

Motivasi siswa tentang meningkat tidaknya pemahaman siswa dengan menggunakan media LCD Proyektor menunjukkan bahwa responden menyatakan meningkat pemahamannya $(91,17 \%)$ termasuk dalam kategori sangat tinggi. Hal ini menunjukkan bahwa pada umumnya pemahaman responden meningkat dengan menggunakan media LCD Proyektor. Respon siswa tentang perlu tidaknya menggunakan media LCD Proyektor diterapkan oleh guru yang menunjukkan bahwa $100 \%$ atau seluruh responden menyatakan perlu diterapkan termasuk dalam kategori tinggi sekali.

Respon siswa tentang termotivasi tidaknya siswa untuk memperhatikan dengan baik dalam pembelajaran menggunakan media LCD Proyektor 
menunjukkan bahwa seluruh responden menyatakan termotivasi untuk bekerja sama dengan baik dalam kelompok $(91,17 \%)$ termasuk dalam kategori tinggi sekali. Respon siswa tentang sulit tidaknya siswa dalam memahami materi yang diberikan guru dengan menggunakan media LCD Proyektor menunjukkan bahwa responden menyatakan tidak sulit $(97,05 \%)$ termasuk dalam kategori tinggi sekali. Hal ini menunjukkan bahwa kebanyakan responden merasa mudah memahami pembelajaran dengan menggunakan media LCD Proyektor.

\section{B. Pembahasan}

Berdasarkan hasil observasi dari pelaksanaan siklus 1, diketahui bahwa guru sudah mampu membuat dan menyusun semua rencana pelaksanaan pembelajaran, namun masih ada sedikit kekurangan. Saat proses pembelajaran, guru sudah dapat menggunakan media LCD Proyektor dengan baik dalam pembelajaran Pendidikan Agama Islam meskipun masih kurang bervariasi dalam penyajiannya karena ini baru pertama kali diterapkan dalam pembelajaran. Pengamatan dan penilaian terhadap aktivitas siswa yang dilakukan oleh pengamat diperoleh data bahwa semua siswa antusias mengikuti pelajaran, namun pada aspek keaktifan dalam mengerjakan tugas, hanya siswa yang tergolong pandai saja yang aktif mengerjakan tugas. Pengelolaan pembelajaran yang dilakukan oleh guru secara keseluruhan telah berlangsung cukup baik, namun pengamat menilai bahwa pengelolaan waktu belum sepenuhnya berhasil. Selain itu, aspek pemberian motivasi belajar kepada siswa juga dirasakan masih kurang.

Berdasarkan hasil observasi siklus 2, diketahui bahwa guru sudah mampu membuat dan menyusun semua rencana pelaksanaan pembelajaran menggunakan media LCD Proyektor dengan baik dalam pembelajaran Pendidikan Agama Islam. Pengamatan dan penilaian terhadap aktivitas siswa yang dilakukan oleh pengamat diperoleh data bahwa semua siswa antusias mengikuti pelajaran. Semua aspek aktivitas siswa pada pembelajaran sudah terpenuhi dan termasuk dalam kategori sangat baik. Hasil pengamatan dan penilaian terhadap aktivitas guru dalam mengelola pembelajaran Pendidikan Agama Islam menggunakan media LCD Proyektor meningkat. Perbedaan siklus 1 dan siklus 2 dapat dilihat pada Tabel 13.

Tabel 13. Perbedaan Siklus 1 dan Siklus 2

\begin{tabular}{|c|c|c|c|c|}
\hline \multirow[t]{2}{*}{ Penilaian/Pengamatan } & \multicolumn{4}{|c|}{ Nilai rata-rata } \\
\hline & Siklus 1 & Kategori & iklus 2 & ategori \\
\hline & $76,13 \%$ & $\mathrm{~B}$ & $2,95 \%$ & $\mathrm{~B}$ \\
\hline siswa di kelas Aktivitas guru di & $69,64 \%$ & $\mathrm{CB}$ & $2,14 \%$ & B \\
\hline kelas & $70,83 \%$ & $\mathrm{CB}$ & $2,49 \%$ & B \\
\hline tan aktivitas siswa & $69,63 \%$ & $\mathrm{CB}$ & $6,79 \%$ & $\mathrm{~B}$ \\
\hline tan aktivitas guru & $72,49 \%$ & $\mathrm{CB}$ & $8,33 \%$ & B \\
\hline & 358,72 & & 102,70 & \\
\hline -rata & $71,74 \%$ & $\mathrm{CB}$ & $0,54 \%$ & $\mathrm{~B}$ \\
\hline
\end{tabular}

an : B (Baik); CB (Cukup Baik)

Melihat data pada Tabel 13 diketahui bahwa baik penilaian RPP, aktivitas siswa maupun guru di kelas, pengamatan aktivitas siswa dan guru sudah masuk kategori cukup baik dengan nilai rata-rata $(71,74 \%)$ pada siklus 1 dan kategori baik dengan nilai rata-rata $(80,54 \%)$ pada siklus 2. Dengan demikian indikator pencapaian sudah terlampaui atau dengan kata lain penelitian dihentikan karena sudah memenuhi sasaran.

Hasil wawancara guru dan angket siswa menunjukkan bahwa guru dan siswa setuju menggunakan media LCD Proyektor dalam pembelajaran Pendidikan 
Agama Islam karena media ini sangat membantu dan memudahkan proses pembelajaran.

\section{PENUTUP}

Kesimpulan dari penelitian ini yakni supervisi akademik dapat meningkatkan kemampuan guru Pendidikan Agama Islam dalam menggunakan media pembelajaran LCD Proyektor SMP Negeri 3 Marabahan. Guru Pendidikan Agama Islam sudah optimal dalam pembelajaran menggunakan media pembelajaran LCD Proyektor.

Respon dan persepsi guru dan siswa terhadap pembelajaran Pendidikan Agama Islam dalam menggunakan media LCD Proyektor sangat baik, yaitu guru dan siswa setuju diterapkannya pembelajaran menggunakan media LCD Proyektor dalam pembelajaran Pendidikan Agama Islam karena media ini sangat membantu dan memudahkan proses pembelajaran.

\section{DAFTAR PUSTAKA}

Ditjend PMPTK. (2008). Petunjuk Teknis Penelitian Tindakan Sekolah ( School Action Research). Jakarta. Djamarah, S.B dan Aswan, Z. (2006). Strategi Belajar Mengajar . Rineka Cipta. Jakarta.

Rudi Susilana dan Cepy Riyana. (2007). Media Pembelajaran Hakikat, Pengembangan Pemanfaatan dan Penilaian. Wacana Prima. Bandung.

Slameto. (2003). Belajar dan FaktorFaktor Yang Mempengaruhinya. Rineka Cipta. Jakarta 
Jurnal PTK \& Pendidikan

Vol. 3 No. 1. Januari - Juni 2017 (41-50) 